\title{
MOTIF BATIK SEBAGAI IKON DAN MITOS BARU IDENTITAS KABUPATEN LEBAK
}

\section{BATIK MOTIF AS A NEW ICON AND MITES OF LEBAK DISTRICT IDENTITY}

\author{
Kurnia Trijaya Apriyani, Imam Setyobudi, Sriati Dwiatmini \\ kurniatrijaya@gmail.com \\ Prodi Antropologi Budaya, Fakultas Budaya dan Media \\ Institut Seni Budaya Indonesia Bandung \\ Artikel diterima: 23 Maret 2021 || Artikel direvisi: 06 April 2021 || Artikel disetujui: 14 April 2021
}

\begin{abstract}
ABSTRAK
Permasalahan penelitian ini ialah bagaimana proses terbentuknya mitos baru yang berupa dua-belas motif batik Lebak dari sisi historis menjadi ikon bagi identitas daerah Lebak. Tujuan penelitian adalah menjelaskan proses pertanda yang bersifat ikonik yang berwujud motif batik sebagai identitas sebuah daerah yang merupakan mitos baru menurut perspektif semiotika pos-struktural. Manfaat teoretisnya adalah mengembangkan penelitian antropologi tentang batik dalam pendekatan semiotika. Manfaat praktisnya berupa pengetahuan mengenai batik sebagai sebuah identitas daerah Kabupaten Lebak. Metode penelitian adalah kualitatif dengan teknik pengumpulan data melalui studi pustaka, wawancara, dan dokumentasi. Populasi penelitian adalah empat belas orang masyarakat Kabupaten Lebak yang dibagi sesuai jenis pekerjaan. Variabel penelitian meliputi ikon, mitos, dan identitas.

Hasil penelitian menemukan bahwa kedua-belas motif batik Lebak yang terinspirasi dari potensi kekayaan daerah dianggap sebagai cermin dari Kabupaten Lebak. Berkaitan dengan itu, Pemerintah daerah Kabupaten Lebak juga membuat kebijakan perihal dua-belas motif batik yang dijadikan ikon bagi identitas Kabupaten Lebak.
\end{abstract}

Kata kunci: Batik Lebak, Identitas, Ikon, Mitos

\section{ABSTRACT}

The case of this study is to analyze how the process the new mites was formed which is in the form of twelve Batik Lebak design from the history, and it has been an icon of Lebak region identity. The purpose of this research was explain about the process that is iconic which is Batik design formed as an region identity that is the new mites according to semiotics perspective post-structural. The benefit of the theory is developing anthropology research about batik in the term of semiotics approach. Another benefit is a science that related to Batik as an identity of Lebak Regency. The method of this research is qualitative by collected of the data through references, interview, and documentation. The population of this research took fourteen people from Lebak Regency which is divided according to their Profession. The variables of the research are icon, mites, and Identity.

The result of the research found out that twelve Batik of Lebak which was inspired of region wealth as an reflected of Lebak Regency. Because of that the Government of Lebak Regency made a policy about twelve Batik design as an Identity of Lebak Regency.

Keywords: Batik Lebak, Identity, Icon, Mites 


\section{PENDAHULUAN}

Batik adalah kain tekstil hasil karya leluhur bangsa Indonesia yang di dalamnya memadukan antara seni dan teknologi. Dalam sehelai kain batik terdapat corak dan ragam motif yang mengandung makna dan memberikan informasi tentang identitas, adat, stratifikasi sosial, pengetahuan dan keterampilan, keadaan alam, dan suatu peristiwa yang terjadi. Batik Indonesia juga dikenal kaya akan filosofi, simbol, teknik, dan budaya yang berhubungan dengan kehidupan masyarakat (Susanto, 2018).

Pada tahun 2015, pemerintah Kabupaten Lebak telah resmi menetapkan dua-belas motif batik baru dengan corak dan karakter yang menggambarkan kekhasan potensi daerah berikut kehidupan masyarakatnya beserta destinasi wisata unggulan. Unesco telah menetapkan batik sebagai warisan kemanusiaan untuk budaya lisan dan non-bendawi (Masterpieces of the Oral and Intangible Heritage of Humanity) milik bangsa Indonesia, pada 2 Oktober $2009^{1}$. Dengan demikian, Indonesia identik dengan batik. Motif batik Indonesia begitu terkenal di dunia. Bahkan, tokoh perdamaian dunia peraih nobel perdamaian 1993, seorang pejuang anti apartheid di Afrika Selatan, mendiang Nelson Mandela selalu berpakaian resmi batik khas Indonesia dalam berbagai kesempatan penting. ${ }^{2}$

Oleh karena itu, setiap daerah di Indonesia, terutama di pulau Jawa, seolah-olah timbul suatu dorongan untuk membuat motifmotif batik yang memiliki ciri karakter khas suatu daerah. Setiap daerah berlomba-lomba menggali dan menghidupkan kembali motif batik khas daerah masing-masing. Bahkan, suatu daerah yang kemungkinan besar belum memiliki motif batik khas daerahnya sendiri, ikut terpacu menciptakan kreasi sendiri yang bermotif khas daerahnya yang berbeda dengan daerah lainnya.

\footnotetext{
2 Oktober 2009, UNESCO Akui Batik sebagai Warisan Dunia dari Indonesia, diakses 6 Februari 2020, https://nasional.kompas.com/read/2017/10/02/08144021/ 2-oktober-2009-unesco-akui-batik-sebagai-warisan-du nia-dari-indonesia.
}

Fenomena dan gejala demikian menarik menjadi bahan penelitian. Penelitian tentang batik bukan hal baru. Penelitian sebelumnya, Pratiwi (2017) telah meneliti tentang batik yang fokus pada motif, makna simbolik, dan visual estetis batik Baduy. Namun demikian, Pratiwi belum melihat proses terbentuknya sebuah motif batik menjadi ikon dan mitos baru bagi identitas suatu daerah.

Penelitian lainnya terlihat penggunaan analisis semiotika Barthes dengan model denotasi dan konotasi. Beberapa di antaranya Kurniasih dan kawan-kawan (2016) meneliti pada aspek nilai sejarah, eksistensi, dan makna simbol yang terdapat pada motif batik khas Depok (Provinsi Jawa Barat). Penelitian ini menunjukkan proses yang terjadi dalam pemaknaan masyarakat terhadap ragam batik Depok. Dwi (2016) melakukan penelitian tentang identitas Kota Yogyakarta yang sengaja dikonstruksi oleh sebuah cenderamata kaos oblong dalam kreasi grafisnya. Wihardi (2014) melakukan penelitian terhadap pergeseran makna yang terjadi pada kasus batik Yogyakarta dan Surakarta. Penelitian yang lebih lama lagi, Pratitasari (2004) telah memulai kajian terhadap proses pencitraan yang muncul dalam kasus umpatan dagadu menjadi bernilai jual sebagai produk cinderamata kaos oblong yang ikonik Kota Yogyakarta.

Landasan teori yang digunakan, semiotika Roland Barthes. Problem studi Barthes memperkarakan hubungan antara teks dan pemaknaannya. Semiotika Barthes menyelidiki pemaknaan pada tingkat dua yang berupa konotasi atau sistem sekunder (Setyobudi 2020: 41-44). Dengan demikian, dalam penelitian ini memperkarakan hubungan antara motif batik Lebak sebagai ikon daripada identitas suatu daerah, yakni Kabupaten Lebak.

\footnotetext{
2 Alasan Nelson Mandela Gemar Pakai Batik di Forum Dunia, diakses 6 Februari 2020, https://lifestyle.kom pas.com/read/2019/05/08/130000020/alasan-nelson-man dela-gemar-pakai-batik-di-forum-dunia?page=all.
} 
Sejumlah penelitian terdahulu terlihat belum ada yang melakukan penelitian tentang motif batik Lebak sebagai materi pencitraan yang sengaja digunakan menjadi ikon dan mitos baru suatu identitas daerah Kabupaten Lebak. Dengan demikian, penelitian ini mengembangkan penelitian-penelitian terdahulu, pada objek materi dan lokus yang berbeda dengan yang sebelumnya.

Sejauh ini, batik masih dominan dikenal berasal dari Yogyakarta, Surakarta, Cirebon, dan Pekalongan. ${ }^{3}$ Padahal penghasil batik bukan hanya terpusat pada sejumlah kota saja. Pemerintah lewat Dinas Perindustrian dan Perdagangan membantu setiap daerah untuk mengembangkan motif batik yang mencirikan keunikan dan daya tarik sebuah daerah (Susanto 2018), termasuk di Kabupaten Lebak.

Pemerintah daerah Kabupaten Lebak menganggap motif batik Baduy belum memenuhi ciri khas dan karakter potensi daerah Lebak. Oleh karena itu, pemerintah daerah melalui Dinas Perindustrian dan Perdagangan sengaja memprakarsai pembuatan dua-belas motif yang mencirikan identitas daerah Lebak. Semenjak lima tahun silam (2015), pemerintah Kabupaten Lebak telah resmi memutuskan duabelas motif batik Lebak tersebut. Dengan demikian, perkara ini sangat berkaitan erat dengan proses pembentukan citra dalam sebuah ikon berikut pembentukan mitos baru melalui materi motif batik Lebak. Mitos yang terkait Kabupaten Lebak sudah ada, akan tetapi kreasi kedua-belas motif batik Lebak merupakan mitos barunya.

Oleh karena itu, didasarkan pada perumusan masalah ditetapkan tiga variabel penelitian yakni ikon, mitos, dan identitas. Ketiga variabel tersebut berkorelasi di dalam munculnya permasalahan yang melahirkan pertanyaan penelitian, bagaimana proses terbentuknya mitos baru yang berupa dua- belas motif

\footnotetext{
${ }^{3}$ Mana Saja Sih Kota Penghasil Batik di Indonesia?, diakses 6 February 2020, https://www.kompasiana.co $\mathrm{m} /$ pocutghinashabira2213/5bb2f3a7c112fe33846d543
}

batik Lebak dari sisi historis menjadi ikon bagi identitas daerah Lebak.

Penelitian ini bertujuan menjelaskan proses pertandaan yang bersifat ikonik yang berwujud motif batik sebagai identitas sebuah daerah yang merupakan mitos baru menurut perspektif semiotika pos-struktural.

Penelitian ini diharapkan dapat membantu perkembangan ilmu pengetahuan antropologi, terutama penelitian yang berpegang pada pendekatan semiotika. Objek materi penelitiannya tentang batik yang relatif baru muncul (dibuat) dari suatu daerah yang belum cukup dikenal dengan produk batiknya.

Penelitian ini diharapkan dapat memberi manfaat bagi masyarakat Kabupaten Lebak untuk lebih mengenal identitas daerahnya. Bagi pemerintah daerah dapat memperoleh pengetahuan dari hasil kajian ini nantinya. Terutama yang berkaitan erat dengan perbatikan.

\section{METODA}

Penelitian ini menggunakan metode penelitian kualitatif yang sumber data penelitiannya berupa, fakta konkret seperti tingkahlaku dan tata-kelakuan orang, percakapan dan ucapan orang, hal-hal tertulis dan visual (motif batik), artefak-artefak budaya lainnya (Setyobudi 2020: 19-20). Teknik pengumpulan data melalui studi pustaka, observasi, dan metode wawancara terbuka pada pihak terkait untuk mendapatkan penjelasan, pandangan, dan pemaknaan masyarakat mengenai batik Lebak sebagai objek yang diteliti.

Penelitian ini membutuhkan dua jenis data, yakni data primer dan data sekunder. Sumber data primer diperoleh dari hasil wawancara secara langsung. Misalnya, Disperindag dan Disbudpar Kabupaten Lebak yang selaku perencana yang mengurusi pembuatan batik Lebak dari awal hingga peluncuran secara resmi, juga masyarakat Kabupaten Lebak itu

2/mana-saja-sih-kota-penghasil-batik-di-indonesia-ini5-kota-terpopuler?pa ge=all. 
sendiri.

Sedangkan, sumber data sekunder yang digunakan yaitu karya ilmiah baik berupa jurnal, tesis, disertasi, dan artikel. Selain itu buku, situs internet, dan dokumen-dokumen yang mempunyai keterkaitan sesuai penelitian ini. Dengan data ini penulis akan mendapatkan mengenai perkembangan batik dan penerapan teori yang akan digunakan.

\section{HASIL DAN PEMBAHASAN}

\section{A. Kebijakan pemerintah terkait batik}

Teknologi membuat batik bukan hanya dikenal di Indonesia, melainkan juga di beberapa negara lain, seperti India, Malaysia, Cina, Thailand, dan Jepang juga terdapat kain yang dibuat dengan cara pembuatan gambar dan warna di atas kain dengan menggunakan lilin wax resist dyeing seperti halnya proses membatik (Susanto, 2018). Maka dari itu, untuk melindungi batik sebagai salah satu produk perdagangan Kementerian Perindustrian mengeluarkan Batikmark "batik INDONESIA" sebagai tanda yang menunjukan identitas dan ciri dari batik buatan Indonesia dalam Peraturan Menteri Perindustrian Republik Indonesia Nomor 74/M-IND/PER/9/2007. Jenis batik yang dimaksud dalam Permenperin tersebut ialah batik tulis, batik cap, dan batik kombinasi antara tulis dan cap.

Batik Indonesia memiliki kekhasan dan keunikan dalam corak dan motifnya yang berisi nilai-nilai atau perlambangan dari latar belakang penciptaan, penggunaan, dan penghargaan yang dimilikinya. Bahkan bagi Euis Saedah selaku Dirjen Industri Kecil Menengah (IKM) Kementerian Perindustrian $2013^{4}$ berpendapat bahwa batik memiliki latar belakang multidimensi yang bisa berbicara tentang sesuatu, karena setiap motif yang dibuat memiliki filosofi hingga penggunaan warna yang digunakan dalam batik juga mempunyai tujuan tertentu. Hal inilah yang membedakan motif batik Indonesia dengan motif-motif dari negara lain.
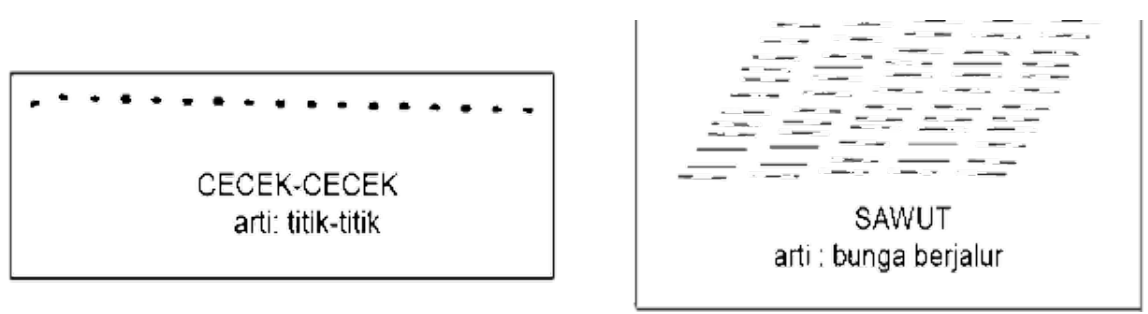

Gambar 1. Motif cecek dan motif sawut.

(Sumber: Universitas Negeri Yogyakarta)

Motif batik Indonesia memiliki desaindesain dengan variasi yang beragam, berbeda dari negara lain yang umumnya bermotif geometris. Misalnya pada motif batik dari India yang tidak terdapat ornamen tumpal, pohon hayat, garuda, dan isen cecek-sawut. Terlebih motif cecek-sawut menjadi ciri khas atau corak khusus karena hanya terdapat pada batik Indonesia. Motif cecek-sawut ialah gabungan antara deretan titik-titik dengan garis-garis sejajar (Susanto, 2018).
Penggunaan batik dalam kehidupan masyarakat Indonesia merupakan salah satu bentuk komunikasi non-verbal yang dapat menunjukkan identitas seseorang baik identitas kulturalnya seperti budaya dan kelas sosial maupun identitas dirinya sendiri. Hal ini dikarenakan motif yang terdapat pada kain batik Indonesia memiliki makna ganda khususnya dalam batik kontemporer, yang pertama dapat mengekspresikan kebudayaan, pekerjaan

\footnotetext{
${ }^{4}$ Wawancara dalam majalah Kina 2013
} 
hingga status sosial. Kedua, untuk mengkomunikasikan bahwa adanya motif modern membuat batik terlihat lebih menarik untuk digunakan dan tidak ketinggalan zaman (Sarmini, 2009).

Perkembangan batik dari waktu ke waktu membawa nuansa baru dalam keberagaman motif yang lebih luas, bebas, dan tidak terpaku pada bentuk ataupun ornamen seperti batik klasik. Munculnya motif batik kontemporer didukung dengan Undang-Undang Nomor 28 Tahun 2014 tentang Hak Cipta. Pada pasal 40 ayat (1) huruf j menyatakan bahwa "karya seni batik adalah motif batik kontemporer yang bersifat inovatif, masa kini, dan bukan tradisional." Karya seni batik ini dilindungi karena mempunyai nilai seni yang berkaitan dengan gambar, corak, maupun komposisi warna juga untuk menghindari tingginya tingkat pembajakan yang dapat merugikan hak moral dan hak ekonomi bagi pencipta batik kontemporer tersebut.

Keberagaman motif batik Indonesia sudah dikenal sampai mancanegara hingga diakui oleh UNESCO sebagai warisan kemanusiaan milik bangsa Indonesia. Pengakuan internasional ini yang menjadi latar belakang Keputusan Presiden Republik Indonesia Nomor 33 Tahun 2009 tentang Hari Batik Nasional yang jatuh pada tanggal 2 Oktober setiap tahunnya. Penetapan Hari Batik Nasional ini bertujuan untuk menumbuhkan rasa kebanggaan dan kecintaan masyarakat terhadap budayanya. Selain itu, dalam rangka meningkatkan pelestarian akan keberadaannya, batik dalam Undang-Undang Nomor 11 Tahun 2010 tentang Cagar Budaya ditetapkan sebagai benda cagar budaya yang bersifat bergerak karena sifatnya yang mudah dipindahkan.

Di samping itu, batik juga menjadi pakaian dinas wajib bagi pegawai negeri sipil yang diatur dalam Peraturan Menteri Dalam Negeri Nomor 53 Tahun 2009 tentang pakaian dinas pegawai negeri sipil di lingkungan departemen dalam negeri dan pemerintah daerah. Berkaitan dengan Permendagri tersebut pemerintah daerah Kabupaten Lebak mengeluarkan Surat Edaran Setda Lebak Nomor 065/501Setda 2016 mengenai penggunaan batik Lebak setiap hari Kamis dan Jumat sebagai pakaian dinas harian. Peraturan ini sesuai dengan Pasal 2 ayat (3) huruf a bahwa "pakaian dinas di lingkungan pemerintah Kabupaten/Kota ialah PDH batik dan/atau tenun ikat dan/atau kain ciri khas daerah", maka penggunaan batik Lebak sudah dianggap sebagai kain ciri khas Kabupaten Lebak.

\section{B. Sejarah industri batik di Kabupaten Lebak}

Masyarakat suku-bangsa Baduy mengatakan bahwa kain batik Baduy sudah ada sejak abad ke- 17 (Pratiwi, 2017). Tapi, jika merujuk pada kata industri dalam Kamus Besar Bahasa Indonesia yang berarti melakukan proses atau pengolahan barang dengan menggunakan sarana dan peralatan maka perkembangan industri batik di Kabupaten Lebak baru dimulai pada tahun 2015. Karena selama ini tidak ada proses membatik di wilayah Baduy maupun didaerah Kabupaten Lebak lainnya (Virgojanti, 2016: 16).

Menurut Sutisna ${ }^{5}$ selaku KASI aneka industri Dinas Perindustrian dan Perdagangan Kabupaten Lebak, menerangkan bahwa industri batik di Kabupaten Lebak dimulai seiring dibuatnya batik Lebak. Karena batik Baduy bukanlah batik asli atau batik khas daerah. Selain itu, ternyata batik Baduy yang selama ini dikenal bukan dibuat menggunakan teknik batik tulis atau cap, melainkan hasil printing atau cetak yang diproduksi di Bandung dan hanya dijual di Kabupaten Lebak. Berbeda dengan batik Lebak yang dibuat menggunakan teknik batik cap dan diproduksi langsung di Kabupaten Lebak.

\footnotetext{
${ }^{5}$ Wawancara 29 Juli 2020
} 


\section{Produksi batik Kabupaten Lebak}

Batik Lebak diproduksi oleh industri kecil menengah (IKM) yang memanfaatkan sumber daya masyarakat sekitar. Menurut Muhamad Alwi ${ }^{6}$ selaku duta koperasi Lebak 2018 terdapat tiga IKM yang aktif memproduksi batik Lebak diantaranya Imah Batik Sahate yang berlokasi di Kec. Rangkasbitung, Sanggar Puspita Romansa di Kec. Kalang Anyar, dan Galeri Chanting Pradana di Kec. Cibadak. Ketiga IKM ini memproduksi Batik Lebak menggunakan teknik batik cap.

Proses pembuatan batik Lebak dengan teknik cap terdiri dari delapan tahapan, pertama menyiapkan kain di atas meja datar yang sudah dilapisi dengan alas lunak. Kedua, merebus malam atau lilin hingga mencair dan tetap menjaga cairan di suhu 60-70 derajat celcius. Ketiga, memasukan bagian bawah alat cap dalam cairan malam atau lilin sekitar dua $\mathrm{cm}$. Keempat, cap diletakkan pada kain yang sudah disiapkan lalu tekan dengan kekuatan yang cukup agar malam atau lilin meresap ke dalam kain hingga menembus ke sisi lainnya. Kelima, setelah proses pengecapan selesai kain dicelupkan kedalam tangki yang berisi pewarna. Keenam, setelah selesai proses pewarnaan, kain direbus untuk memunculkan warna dasar kain dan warna hasil pewarnaan. Ketujuh, kain dibersihkan dengan menggunakan soda agar terlihat lebih cerah. Terakhir, kain dijemur dan di setrika setelah kering (Fajri: 2019).

Menurut Bapak Sutisna pembuatan batik Lebak yang masih menggunakan teknik cap ini dikarenakan masih kurangnya sumber daya manusia untuk memproduksi batik tulis. Maka dari itu, Dinas Perindustrian dan Perdagangan Kabupaten Lebak terus melakukan pelatihan dan memberikan bantuan peralatan produksi batik agar supaya masyarakat dapat

\footnotetext{
${ }^{6}$ Wawancara 7 Agustus 2020

73 Oktober 2018, Peringatan Hari Batik: Menjaga Warisan Adiluhung, Mendongkrak Ekonomi Masyarakat, diakses 12 Agustus 2020, https://kabarbanten.pikiran .rakyat.com/lebak/pr-59613165/peringatan-hari-batik-m enjaga-warisan-adiluhung-mendongkrak-ekonomi-mas
}

membuka sentra usaha batik yang permintaan setiap tahunnya terus meningkat.

Adapun meningkatnya permintaan terhadap batik Lebak dikarenakan gencarnya promosi yang dilakukan agar batik Lebak lebih dikenal oleh masyarakat luas. Bukan hanya mengikutsertakan dalam pameran lokal dan regional Banten, batik Lebak juga ikut meramaikan pameran-pameran tingkat nasional misalnya pada ajang Jakarta Fashion \& Food Festival (JFFF) tahun $2017^{7}$ dan Gebyar Agenda Pariwisata dan Industri Batik Nasional di Surabaya tahun $2018^{8}$. Peningkatan ini juga dikarenakan batik mulai diminati oleh kaum muda sebagai pakaian sehari-hari.

\section{Dasar pertimbangan}

Mengingat penggunaan batik Baduy yang terus berkembang di masyarakat dan sebagai upaya untuk melestarikannya Pemerintah Kabupaten Lebak melalui Dinas Perindustrian dan Perdagangan mencoba mendaftarkan hak cipta batik Baduy, namun ternyata batik Baduy tidak dapat diklaim sebagai batik khas Baduy. Hal tersebut berdasarkan asal usul motif yang ada pada batik Baduy banyak mengandung motif milik daerah lain. Selain itu, tidak adanya proses produksi batik di wilayah Kabupaten Lebak, dan batik Baduy yang selama ini dikenal masyarakat bukan karena motifnya tetapi pada karakter warnanya yakni hitam dan biru. Sementara, warna tidak dapat diklaim milik suatu daerah (Virgojanti, 2016: 15-16).

Karena batik Baduy tidak mengandung motif yang berasal dari ciri khas dan potensi budaya daerah maka timbul suatu keinginan dari Pemerintah Kabupaten Lebak untuk membuat batik dengan motif yang mencerminkan identitas daerah Lebak.Sehubungan dengan

yarakat.

88 April 2018, Batik Lebak jadi Magnet di Pameran Surabaya, diakses 12 Agustus 2020, https://kabarbanten. pikiran.rakyat.com/pariwisata/amp/pr-59610623/batik-1 ebak-jadi-magnet-di-pameran-surabaya. 
itu, Dinas Perindustrian dan Perdagangan Kabupaten Lebak berinisiatif untuk membuat batik dengan motif yang diambil dari berbagai bidang potensi yang ada seperti seni, budaya, sumber daya alam, dan adat istiadat dari masyarakat suku-bangsa Baduy, dan juga Kasepuhan Lebak Selatan. Semua itu terangkum dalam dua-belas motif batik Lebak yang terdiri dari motif angklung buhun, caruluk saruntuy, gula sakojor, kahirupan Baduy, leuit sijimat, rangkasbitung, sawarna, kalimaya, sadulur, Lebak bertauhid, seren taun, dan pare sapocong.

Pemilihan nama yang diberikan pada dua- belas motif tersebut disesuaikan dengan potensi yang ada misalnya motif kalimaya, nama ini diambil karena kalimaya merupakan ikon kekayaan alam yang dimiliki Kabupaten Lebak dan sudah terkenal di mancanegara. Selain itu, untuk penentuan jumlah dibuatnya kedua-belas motif tersebut Pemerintah Kabupaten Lebak tidak memiliki alasan khusus, Bapak Sutisna menjelaskan bahwa;

\begin{abstract}
"Yaitu karena hasil potensi yang ditemukan di Kabupaten Lebak banyak juga. Sebenarnya mau jumlah motifnya satu atau berapapun juga ga apa-apa, cuma emang ciri khas sama potensi yang kita punya banyak jadi hasilnya pun banyak". (Wawancara, 29 Juli 2020)
\end{abstract}

Sedangkan untuk corak warna yang pertama kali diluncurkan ialah warna hitam dan biru yang sudah dikenal sebagai karakter dari batik Baduy juga warna coklat dan hitam dari karakter wilayah Kasepuhan Lebak Selatan (Virgojanti, 2016: 19). Tapi, dalam perkembangannya batik Lebak diproduksi dengan berbagai macam warna seperti merah, hijau, putih, dan emas mengikuti permintaan pasar karena mengingat warna tidak dapat diklaim milik suatu daerah.

\footnotetext{
93 Januari 2018, Selayang Pandang Batik Lebak, diakses
} 15 Agustus 2020, http://disperindag.lebakkab.go.id/home
Kedua-belas motif batik ini resmi diluncurkan pada masyarakat umum oleh Bupati Lebak pada 2 Desember 2015 yang bertepatan dengan peringatan Hari Ulang Tahun (HUT) Kabupaten Lebak yang ke 187. Selanjutnya pada tahun 2016 batik Lebak kembali dihadirkan dalam kegiatan pemilihan duta pariwisata Kabupaten Lebak agar supaya semakin dikenal oleh masyarakat luas.

Kehadiran dua-belas motif batik yang mencerminkan identitas Kabupaten Lebak ini didukung dengan diserahkannya sertifikat Hak Kekayaan Intelektual (HKI) oleh Kementerian Hukum dan Hak Asasi Manusia (HAM) Provinsi Banten kepada Bupati Lebak pada 25 Januari $2016^{9}$. Hal ini bertujuan untuk menghindari pembajakan karya kreativitas atas motif batik Lebak.

\section{E. Pihak-pihak yang terlibat}

Pada tahapan awal pembuatan keduabelas motif batik Pemerintah Kabupaten Lebak melalui Dinas Perindustrian dan Perdagangan melakukan identifikasi dan menggali potensi yang dapat mencerminkan identitas daerah Lebak. Dalam proses ini juga melibatkan Dinas Pemuda dan Olahraga, Dinas Pariwisata, tokoh adat masyarakat Baduy, dan masyarakat kasepuhan Lebak Selatan.

Selanjutnya, dalam proses pembuatan motif batik Dinas Perindustrian dan Perdagangan bersama tim dari balai besar kerajinan dan batik Yogyakarta melakukan survei secara langsung ke lokasi yang memiliki potensi di Kabupaten Lebak. Survei ini bertujuan untuk melihat kondisi asli terkait potensi daerah Lebak yang akan diilustrasikan ke dalam motif batik. Menurut Bapak Sutisna ${ }^{10}$ kerjasama ini dilakukan karena Yogyakarta sangat berpengalaman dalam proses pembuatan batikdan pusat pelatihan batik secara nasional pun terletak di Yogyakarta.

page/berita/112-selayang-pandang-batik-lebak.html.

${ }^{10}$ Wawancara 29 Juli 2020 
Adapun tokoh masyarakat adat yang ikut memberikan usulannya terkait penciptaan kedua-belas motif batik Lebak adalah $\mathrm{H}$. Ade Sumardi selaku tokoh Kasepuhan Lebak Selatan, Sukanta selaku ketua Kasepuhan Banten Kidul, Saidi sebagai tokoh adatBaduy, Saija selaku kepala desa Kanekes, dan pelaku kerajinan tenun Baduy yaitu Amir Sachin. Bukan hanya itu, tiga budayawan asal Lebak yaitu Wawan Sukmara dari Rangkasbitung, $\mathrm{H}$. Bajaji dari Lebak Selatan, dan Ade Sudrajat asal Sawarna pun turut serta memberikan sumbangsihnya dalam proses perancangan keduabelas motif batik Lebak (Virgojanti, 2016: 18).

\section{F. Profil dua-belas motif batik Lebak}

Motif batik Lebak memiliki karakteristik yang berbeda dari batik daerah lain, karena motif batik ini terinspirasi dari keunggulan daerah Lebak. Berikut adalah profil keduabelas motif batik Lebak ${ }^{11}$ :

\section{Angklung Buhun}

Motif ini diberi nama sesuai alat kesenian tradisional khas daerah Lebak. Angklung brtt/uhun digunakan dalam upacara- upacara adat di masyarakat suku-bangsa Baduy dan kasepuhan Lebak Selatan. Ornamen dalam motif ini terdiri dari angklung, bedug dogdog lojor, leuit, rumah panggung, dan motif hias tenun Baduy yang membentuk geometris.

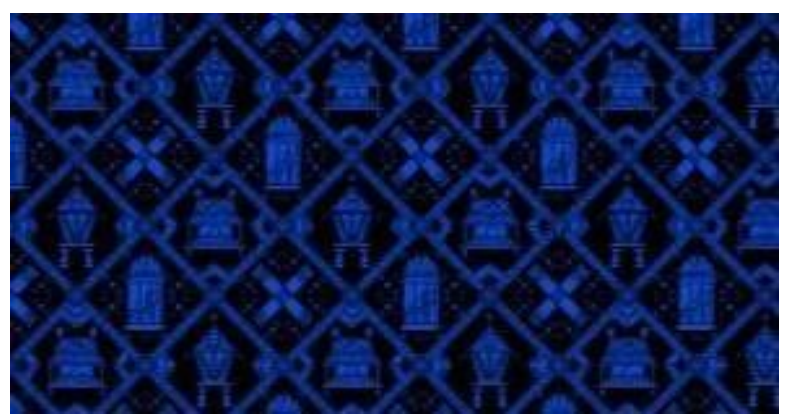

Gambar 2. Motif Angklung Buhun.

(Sumber: Pemerintah Daerah Kabupaten Lebak, 2016)

113 Oktober 2018, 12 Motif Batik Lebak dan Filosofinya, diakses 17 Agustus 2020, http://lebakkab.go.id/2018/10/

\section{Caruluk Saruntuy}

Caruluk merupakan sebutan untuk buah aren bagi masyarakat Lebak. Buah ini biasanya digunakan untuk membuat kolang-kaling, sedangkan saruntuy artinya seuntai. Dalam motif ini terdapat ornamen utama yang terdiri dari buah aren, pelepah daun aren, dan gula sakojor sebagai hasil utama pohon aren. Selain itu, terdapat ornamen tambahan seperti bambu dan batu kalimaya. Motif ini diambil sesuai kekayaan alam yang menjadi sumber ekonomi bagi masyarakat Kabupaten Lebak.

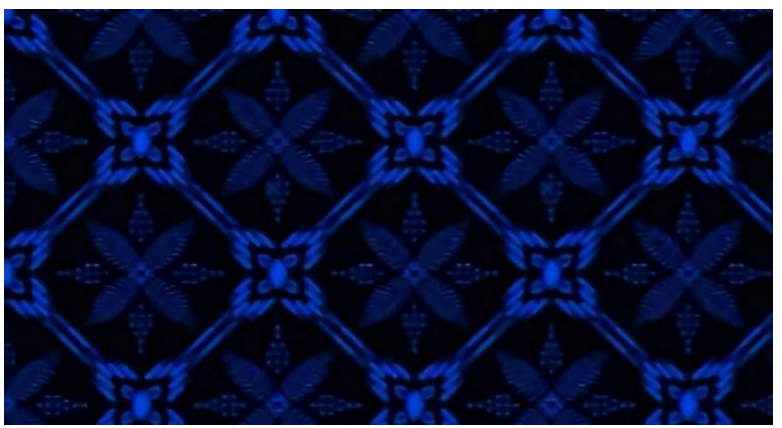

Gambar 3. Motif Caruluk Saruntuy. (Sumber: Pemerintah Daerah Kabupaten Lebak, 2016)

\section{Gula Sakojor}

Motif ini dibuat berdasarkan komoditas unggulan Kabupaten Lebak. Gula aren atau gula merah dari Kabupaten Lebak memiliki keunggulan karena tetap mempertahankan budaya tradisional dalam proses pengolahan dan pengemasan. Biasanya gula ini dijual satu kojor atau satu ikatan yang terdiri dari lima hulu atau disebut juga lima bungkus. Ornamen pada motif ini terdiri dari ikatan gula satu kojor, lodong yang artinya tempat pengambilan nira dari bambu, dan buah mayang sebagai sumber bahan baku air nira. 


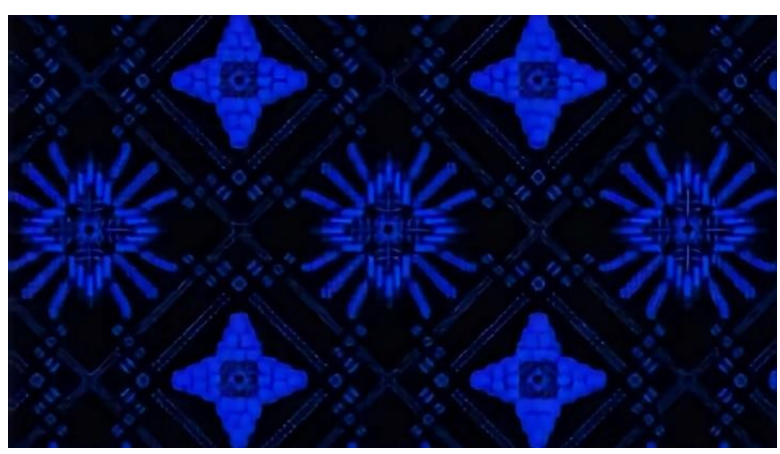

Gambar 4. Motif Gula Sakojor.

(Sumber: Pemerintah Daerah Kabupaten Lebak, 2016)

\section{Kahirupan Baduy}

Ornamen yang ada pada motif ini adalah rumah panggung, lantayan atau tempat penjemuran padi, leuit Baduy, serta pohon aren sebagai ornamen tambahan. Sesuai dengan namanya ornamen pada motif ini diambil dari aktivitas sehari-hari masyarakat sukubangsa Baduy.

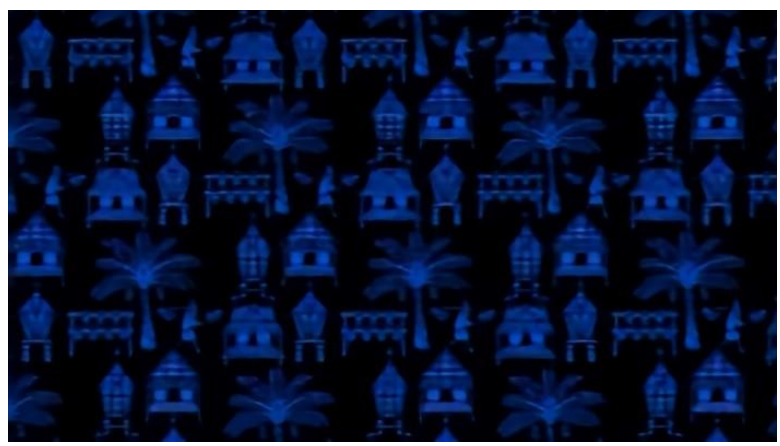

Gambar 5. Motif Kahirupan Baduy.

(Sumber: Pemerintah Daerah Kabupaten Lebak, 2016)

\section{Leuit Sijimat}

Penamaan motif ini terinspirasi dari lumbung atau tempat penyimpanan padi di kasepuhan Lebak Selatan yang terdiri dari kasepuhan Cisungsang, Sinar Resmi, Cigananas, Cicarucub, Cicemet, dan Citorek. Ornamen tambahan dalam motif ini ialah rumah panggung, bedug lojor, dan angklung buhun.

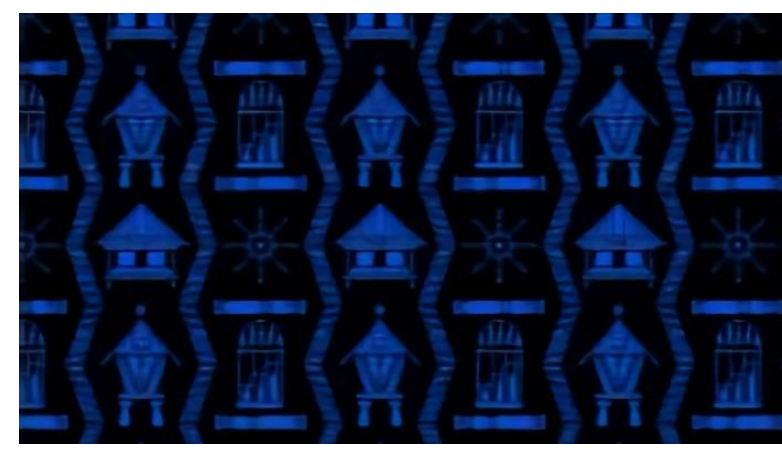

Gambar 6. Motif Leuit Sijimat.

(Sumber: Pemerintah Daerah Kabupaten Lebak, 2016)

\section{Rangkasbitung}

Sesuai dengan sejarahnya penamaan kota Rangkasbitung terinspirasi dari bambu bitung, maka dalam motif ini tampak bambu bitung yang ditata saling terhubung membentuk segi empat. Selain itu, terdapat ornamen tambahan seperti batu kalimaya, gula aren, dan mayang aren yang merupakan gambaran dari potensi sumber daya alam milik Kabupaten Lebak.

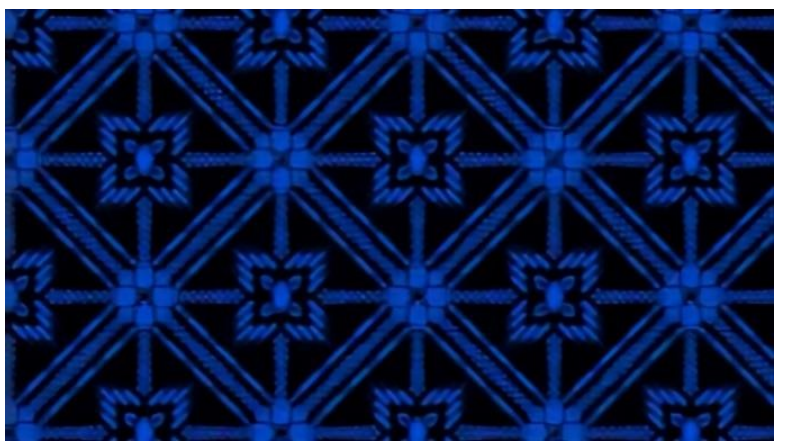

Gambar 7. Motif Rangkasbitung.

(Sumber: Pemerintah Daerah Kabupaten Lebak, 2016)

\section{Sawarna}

Motif ini terinspirasi dari nama salah satu objek wisata pantai unggulan di Lebak Selatan tepatnya berada di Kecamatan Bayah. Unsur ornamen yang ada pada motif ini ialah pohon kelapa, sampan, dan batu karang berbentuk tanjung layar yang merupakan ikon dari pantai Sawarna. 


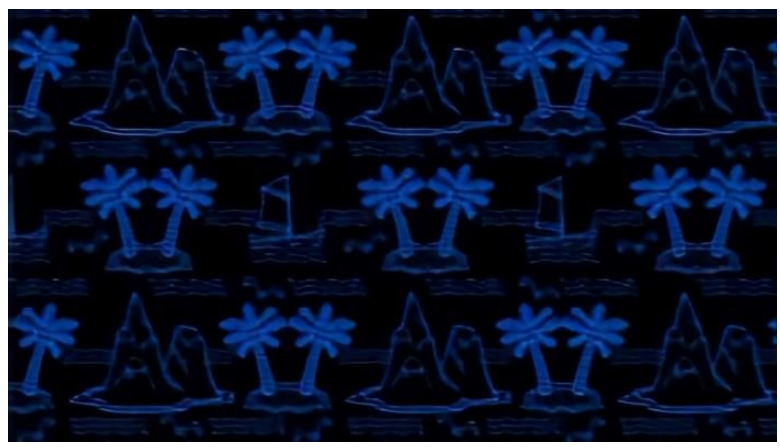

Gambar 8. Motif Sawarna

(Sumber: Pemerintah Daerah Kabupaten Lebak, 2016)

\section{Kalimaya}

Kalimaya merupakan jenis batu mulia yang menjadi ikon kekayaan alam Kabupaten Lebak yang sudah terkenal sampai mancanegara. Batu Kalimaya ini dapat ditemui di Kecamatan Maja, Curugbitung, Sajira, dan Cimarga yang biasanya digunakan sebagai bahan baku pembuatan cincin. Selain batu kalimaya ornamen tambahan dalam motif ini yaitu bambu, angklung, dan salah satu motif dari tenun Baduy.

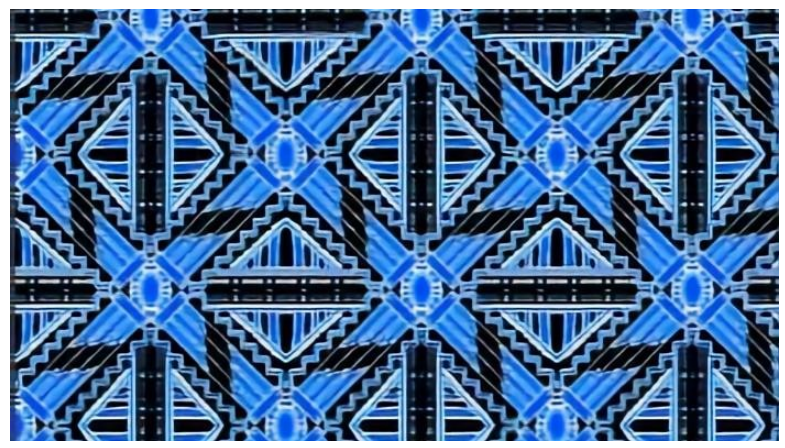

Gambar 9. Motif Kalimaya.

(Sumber: Pemerintah Daerah Kabupaten Lebak, 2016)

\section{Lebak Bertauhid}

Penamaan bertauhid dalam motif ini sesuai dengan moto Kabupaten Lebak yakni bersih, taqwa, hijau, dan damai. Ornamen dari motif ini terdiri dari bedug, surau masjid, dan tenun Baduy.

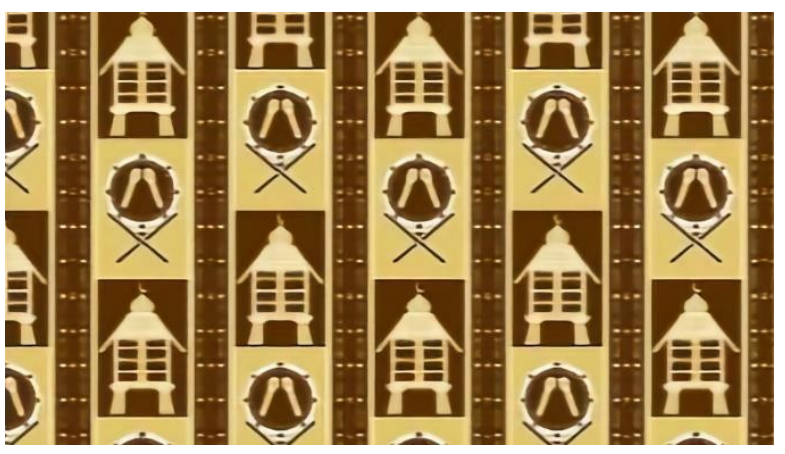

Gambar 10. Motif Lebak Bertauhid.

(Gambar: Pemerintah Daerah Kabupaten Lebak, 2016)

\section{Sadulur}

Sadulur memiliki arti saudara, ornamen utama yang menggambarkan motif ini terdiri dari dua jenis leuit yakni leuit yang biasa digunakan oleh masyarakat Kasepuhan Lebak Selatan dan leuit suku- bangsa Baduy. Walaupun bentuk kedua jenis leuit ini berbeda tetapi memiliki fungsi dan manfaat yang sama untuk penyimpanan padi. Ornamen tambahan dalam motif ini ialah angklung dan motif tenun Baduy.

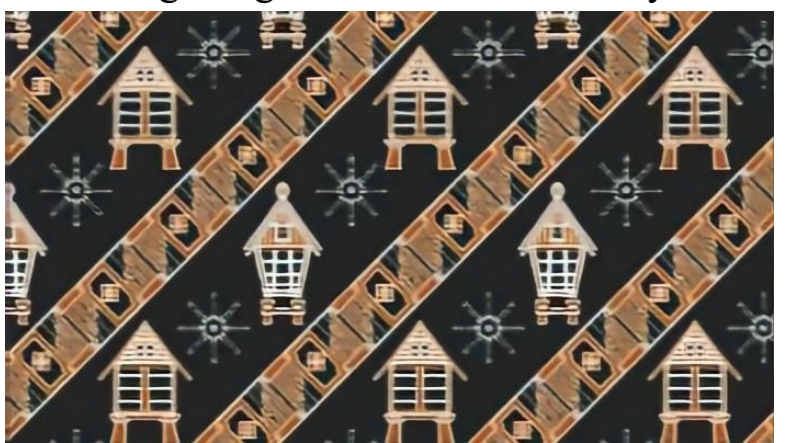

Gambar 11. Motif Sadulur.

(Sumber: Pemerintah Daerah Kabupaten Lebak, 2016)

\section{Seren Taun}

Motif ini diberi nama sesuai ritual yang masih dilaksanakan oleh masyarakat Kasepuhan Lebak Selatan dan sukubangsa Baduy hingga saat ini. Seren taun dilakukan setelah panen karena ritual ini merupakan ucapan syukur kepada Allah SWT atas hasil bumi atau panen yang diperoleh masyarakat. Dalam motif ini terdapat ornamen leuit, 
ikat padi, dan reog reungkong yaitu pengiring dalam upacara seren taun sekaligus alat pengangkut padi dari lantayan ke leuit.

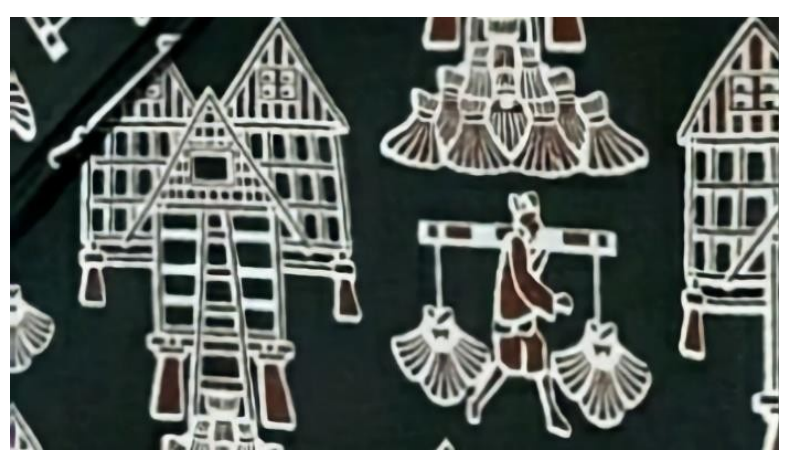

Gambar 12. Motif Seren Taun.

(Sumber: Pemerintah Daerah Kabupaten Lebak, 2016)

\section{Pare Sapocong}

Pare Sapocong merupakan sebutan untuk ikatan padi yang terdiri dari enam genggam bagi masyarakat daerah Lebak. Penamaan sapocong ini dikarenakan bentuk ikatan padi menyerupai ikatan pocong bagi orang yang sudah meninggal. Dalam motif ini terdapat ornamen utama yaitu ikatan padi sedangkan ornamen tambahan berupa leuit dan pola geometris dari motif ikat kepala Kasepuhan Lebak Selatan.

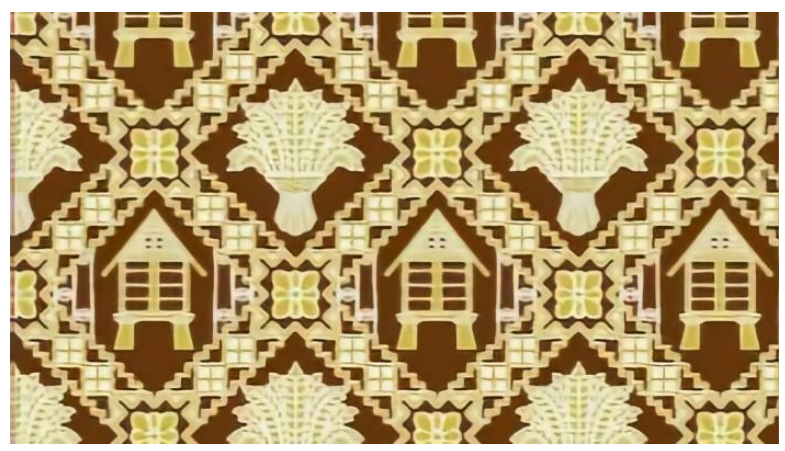

Gambar 13. Motif Pare Sapocong.

(Sumber: Pemerintah Daerah Kabupaten Lebak, 2016)

\section{G. Mitos baru: motif batik sebagai identitas daerah}

\section{Tema Ekonomi Rakyat}

Ekonomi rakyat menggambarkan roda kehidupan ekonomi yang berlangsung pada sebagian masyarakat yang bertopang pada mata pencaharian agraris seperti tanaman padi dan pohon aren.

a. Sebagian warga pedesaan masih bergantung pada pohon aren yang menghasilkan buah aren yang diolah bijinya menjadi buah kolang kaling dan bunganya menjadi air nira untuk membuat gula aren yang kemudian dijadikan ikon daerah berupa motif batik.

Motif Caruluk Saruntuy berperan sebagai penanda pada pemaknaan tingkat kedua dengan petandanya kehidupan bersama dengan memiliki manfaat bagi orang lain. Pemaknaan tingkat kedua ini sesuai dengan pohon aren yang mempunyai banyak manfaat baik biji, buah, pelepah daun, dan air nira yang digunakan masyarakat Kabupaten Lebak untuk membuat olahan makanan yang akhirnya menjadi komoditas dan membantu perekonomian bagi masyarakat.

Sedangkan pada bagan di atas, ekonomi rakyat sebagai tanda di tingkatan pertama berubah menjadi penanda motif gula sakojor dengan petanda yang berkaitan dengan sifat masyarakat Kabupaten Lebak yang saling membantu sehingga memiliki ikatan kekeluargaan yang kuat.

b. Selain bergantung pada pohon aren, rata-rata masyarakat berprofesi sebagai petani. Iklim yang baik membuat hasil panen padi terus berkembang sehingga padi yang diolah menjadi beras merupakan makanan pokok bagi masyarakat yang kemudian dijadikan ikon daerah dalam motif batik. Pare atau padi yang tumbuhnya semakin berisi semakin merunduk merupakan makanan pokok bagi masyarakat Kabupaten Lebak menjadi penanda dan petanda dalam pemaknaan tingkat pertama yang menjadi ekonomi masyarakat sebagai tanda. Pada tingkatan kedua motif Pare Sapocong 
menjadi penanda yang petandanya ialah kemakmuran hidup dan kerendahan hati. Karena, padi dalam motif ini digambarkan dalam satu ikatan yang memberi arti sebagai ikatan persaudaraan antar masyarakat di Kabupaten Lebak.

\section{Tema Potensi Sumber Daya Alam}

Memiliki wilayah yang luas membuat Kabupaten Lebak mempunyai sumber daya alam yang kaya dan menjadi potensi bagi daerah seperti hasil pertambangan dan objek wisata.

a. Dari sekian banyak hasil tambang yang dimiliki batu kalimaya menjadi primadona di kalangan kolektor batu mulia karena keindahan yang dimilikinya. Oleh sebab itu, kemudian dijadikan sebagai ikon daerah berupa motif batik. Motif kalimaya sebagai penanda pada tingkatan kedua memiliki petanda kehidupan yang kuat dengan harmonisasi warna kebajikan. Hal tersebut dianggap berkaitan dengan masyarakat yang selalu sejahtera dalam menjalani kehidupannya.

b. Sebagian wilayah Kabupaten Lebak merupakan pesisir pantai yang memiliki keindahan alam dengan ciri khasnya masing-masing, misalnya pantai Sawarna dikenal dengan batu karang yang menyerupai sebuah layar perahu keunikan inilah yang akhirnya dijadikan sebagai ikon daerah dalam motif batik.

Petanda pada tingkatan kedua dalam motif sawarna ialah nuansa keindahan alam yang penuh kedinamisan. Hal tersebut dianggap sebagai penggambaran salah satu objek wisata yang keindahan alam dan sudah menjadi potensi bagi Kabupaten Lebak.

\section{Tema Profil Daerah}

Profil daerah digambarkan melalui Ibu kota Rangkasbitung yang merupakan tampilan penting dari Kabupaten Lebak yang juga memiliki moto bersih, taqwa, hijau, dan damai.

a. Asal mula penamaan ibu kota daerah berasal dari bambu jenis bitung yang banyak ditemukan di wilayah Kabupaten Lebak yang kemudian dijadikan sebagai ikon daerah dalam sebuah motif batik.

Nama wilayah sebagai tanda pada tingkatan pertama melahirkan motif rangkasbitung sebagai penanda dan ketertiban, keteraturan, dan keharmonisan adalah petanda yang disematkan dalam motif batik sebagai pemaknaan tingkatan kedua. Motif ini dianggap mencerminkan ibukota Rangkasbitung yang sudah tertib baik penataan wilayah maupun masyarakatnya dalam menjalani aturan.

b. Sebagian besar masyarakat Lebak beragama Islam yang kemudian dijadikan sebagai moto daerah karena dianggap mencerminkan kehidupan masyarakat yang religius. Oleh karena itu, moto daerah dijadikan sebagai ikon dalam motif batik. Moto daerah sebagai tanda pada pemaknaan tingkat pertama menghasilkan penanda di tingkat kedua yakni motif Lebak Bertauhid dengan petandanya yaitu citra kehidupan yang religius dengan penuh keimanan dan ketakwaan pada Allah SWT. Hal ini dianggap mencerminkan masyarakat Kabupaten Lebak yang mayoritas beragama Islam dan taat beribadah.

\section{Tema Budaya Masyarakat Adat}

Sebagian warga Kabupaten Lebak sampai saat ini masih mempertahankan adat-istiadat yang digunakan dalam kehidupan sehari-hari misalnya ritual ucapan syukur untuk hasil panen yang melimpah 
dan penggunaan alat musik tradisional.

a. Angklung buhun digunakan sebagai alat kesenian tradisional dalam kegiatan atau upacara bagi masyarakat Kasepuhan Lebak Selatan dan suku-bangsa Baduy. Selain penggunaannya yang membedakan angklung buhun dengan angklung lainnya adalah bahan dasar pembuatan angklung ini menggunakan bambu jenis bitung yakni bambu dengan ukuran yang besar. Oleh karena itu, kemudian dijadikan ikon daerah berupa motif batik.

Petanda dalam motif ini yaitu kedinamisan dan kegembiraan, karena alunan irama, ritme, dan nada yang dimainkan oleh angklung buhun bersifat dinamis juga berkesinambungan. Selain itu, angklung buhun juga digunakan sebagai pengiring upacara adat yang dianggap sebagai ungkapan kegembiraan dan rasa suka cita untuk menghormati para tamu yang hadir dalam upacara adat tersebut.

b. Suku-bangsa Baduy merupakan masyarakat yang masih memegang teguh adat istiadat untuk dalam menjalani aktivitas sehari-hari hal ini menggambarkan kehidupan dalam lembaga tradisi yang kemudian dijadikan ikon daerah pada motif batik. Pada tingkatan kedua motif Kahirupan Baduy dengan petanda kehidupan bersahaja dengan kelestarian alam yang kental akan budaya dianggap mencerminkan kehidupan atau aktivitas sehari-hari masyarakat Baduy yang hidup berdampingan dengan alam. Hal tersebut dibuktikan dengan hasil alam yang diberikan pada pemerintah saat kegiatan Seba yang rutin dilakukan setiap satu tahun sekali. c. Leuit Sijimat digunakan masyarakat sebagai tempat penyimpanan padi sebagai upaya untuk menjaga kebutuhan pangan di masa paceklik yang kemudian dijadikan sebagai ikon daerah dalam motif batik.

Petanda dalam motif Leuit Sijimat ialah lumbung kemakmuran hidup dengan ketahanan pangan yang cukup. Hal tersebut berkaitan dengan kebiasaan masyarakat Kasepuhan Lebak Selatan dan sukubangsa Baduy yang pasti memiliki leuit untuk mengawetkan padi agar kebutuhan pangannya selalu tercukupi meskipun di masa-masa sulit.

d. Ikatan persaudaraan yang terjalin antar masyarakat begitu kuat dilambangkan dengan dua lumbung padi yang berbeda bentuk namun memiliki fungsi yang sama maka dari itu kemudian dijadikan sebagai ikon daerah pada motif batik. Kekeluargaan, kesejahteraan, dan kebersamaan merupakan petanda tingkat kedua dalam motif sadulur yang dianggap sebagai cerminan hubungan yang sangat erat antara masyarakat dan saling bergantung. Walaupun di Kabupaten Lebak terdiri dari berbagai suku, adat, dan perbedaan bahasa tetapi tetap merasa bersaudara.

e. Masyarakat adat dalam menjalani kehidupannya mengikuti aturan adat istiadat yang berlaku, termasuk dalam tradisi upacara ritual sebagai bentuk rasa syukur yang kemudian dijadikan sebagai ikon daerah pada motif batik.

Petanda tingkat kedua yang terdapat dalam motif Seren Taun sesuai dengan tujuan di lakukannya ritual ini yakni sikap rasa syukur atas anugerah kenikmatan dari yang Maha Kuasa. 
Kurnia, Imam, Sriati - Motif Batik Sebagai.....

\section{SIMPULAN}

Permasalahan penelitian ini berfokus pada pertanyaan penelitian mengenai proses terbentuknya mitos baru yang berupa dua- belas motif batik Lebak dari sisi historis menjadi ikon bagi identitas daerah Lebak.

Proses pembentukan dua-belas motif batik sebagai ikon daerah Lebak melalui dua tingkatan yakni denotasi dan konotasi. Pemaknaan pada tingkat pertama atau denotasi hubungan antara penanda dan petanda diambil dari realitas sehingga menghasilkan makna yang eskplisit (harfiah) dan langsung dalam pengertian hubungan penanda dan petanda tetap merupakan arbiter (mana suka atau sewenang-wenang). Makna yang dihasilkan pada tingkat denotasi ini diklasifikasikan dalam empat tema besar, yakni ekonomi rakyat, potensi sumber daya alam, profil daerah, dan budaya masyarakat adat yang sesuai dengan keadaan Kabupaten Lebak.

Sehubungan dengan hal itu, Pemerintah Daerah Kabupaten Lebak berinisiatif membuat kebijakan tentang dua-belas motif batik sebagai ikon identitas daerah kabupaten karena batik telah menjadi bahasa komunikasi non- verbal yang telah diakui secara internasional. Selain itu, batik sendiri sudah memasyarakat di Indonesia. Dengan demikian, representasi identitas daerah melalui dua-belas motif batik ini akan mencapai dua sasaran yang ingin dicapai yakni dikenal secara internasional dan nasional. karena kekhasan motifnya berbeda dari daerah lainnya.

\section{DAFTAR PUSTAKA}

\section{Buku}

Barker, C. (2005). Cultural Studies. Bandung: Mizan Media Utama.

Barthes, R. (2004). Mitologi. Bantul: Kreasi Wacana Offset.

Berger, A. A. (2000). Tanda-Tanda dalam Kebudayaan Kontemporer. Yogyakarta: Tiara Wacana.

Danesi, M. (2012). Pesan, Tanda, dan Makna. Yogyakarta: Jalasutra.
Eco, U. (2009). Teori Semiotika Signifikasi Komunikasi Teori Kode Serta Teori Produksi-Produksi-Tanda. Bantul: Kreasi Wacana.

Setyobudi, I. (2020). Metode Penelitian Budaya. (Desain Penelitian dan Tiga Model Kualitatif: Life history, Grounded Theory, dan Narrative Personal). Bandung: Sunan Ambu Press.

Riyanto, A. (2010). Metodologi Penelitian Sosial dan Hukum. Bandung: Granit.

Sugiyono. (2012). Metode Penelitian Kuantitatif Kualitatif dan $R \& D$. Bandung: Alfabeta.

Susanto, S. (2018). Seni Batik Indonesia. Yogyakarta: Andi Offset.

Virgojanti, dkk. (2016). Batik Lebak dan Tenun Baduy Karya Cita Masyarakat Lebak. Lebak: Dinas Perindustrian dan Perdagangan Kabupaten Lebak.

\section{Jurnal}

Adeng. (2013). Sejarah Sosial Kabupaten Lebak. Patanjala, 1-22.

Andriyanto. (2017). Analisa Semiotika Denotasi, Konotasi, dan Mitos Iklan Indomie versi 45th Anniversary di Televisi. Jurnal Manajemen Bisnis dan Kewirausahaan, 113-121.

Junius, J. (2018). Mitos Seksualitas dalam Iklan. Nyimak Journal of Communication, 1-16.

Mitak, C. N. (2017). Wacana Iklan TelevisiI Rokok Djarum 76 Versi "Pengin Eksis". Jurnal Ilmiah Kebudayaan Sintesis, 95-107.

Kurniasih, dkk. (2016). Penelusuran Makna Motif Batik Depok Melalui Konsep Denotasi dan Konotasi Roland Barthes. Jurnal Desain, 45-57.

Sarmini. (2009). Pakaian Batik: Kulturisasi Negara dan Politik Identitas. Jantra, 674-688.

Wardani, E. D. (2016). Konstruksi Identitas Kota Yogya dalam Kaos Oblong 
Dagadu Djogja. In H. H. Setiajid, Language, Literature, and Society (pp. 200-211). Yogyakarta: Department of English Letters, Faculty of Letters Universitas Sanata Dharma.

Wihardi, D. (2015). Pergeseran Makna Motif Batik Yogyakarta - Surakarta. Makna, 105-113.

\section{Prosiding}

Dwisthi \& Mahadian. (2015). Representasi Wanita Dalam Sampul Album Raisa. Proceeding of Management (pp. 9941007). Bandung: Fakultas Komunikasi dan Bisnis, Universitas Telkom.

\section{Disertasi}

Setyobudi, I. (2020). Komodifikasi Revitalisasi Tradisi di Cihideung Kabupaten Bandung Barat: Analisa Produksi-Diri Masyarakat. Program Doktor Antropologi Pasca FISIP. Bandung: Universitas Padjadjaran.

\section{Tesis}

Pratitasari, S. (2004). Dari 'Matamu!' menjadi Cenderamata. Yogyakarta: Universitas Gadjah Mada.

\section{Skripsi}

Fajri, N. I. (2019). Pemberdayaan Ekonomi Masyarakat melalui Industri Rumahan Batik Lebak pada Komunikasi Chanting Pradana di Kampung Pancur Desa Bojongleles Kecamatan Cibadak Kabupaten Lebak. Banten: UIN Sultan Maulana Hasanuddin.

Pratiwi, I. A. (2017). Kajian Motif Hias dan Makna Simbolik Batik Suku Baduy Banten. Bandung: Universitas Pendidikan Indonesia.

Rizky, L. (2019). Simbol Kepemimpinan Malim Dalam Seni Reak Kuda Lumping Grup Putra Pewaris. Bandung: Institut Seni Budaya Indonesia.

\section{BPS}

Badan Pusat Statistik. 2019. Kabupaten Lebak dalam Angka. Lebak: BPS . 2019. Statistik Daerah Kabupaten Lebak. Lebak: BPS

\section{Undang-Undang dan peraturan pemerintah}

Undang-Undang Nomor 11 Tahun 2010 tentang Cagar Budaya

Undang-Undang Nomor 28 Tahun 2014 tentang Hak Cipta

Keputusan Presiden Nomor 33 Tahun 2009 tentang Hari Batik Nasional

Peraturan Menteri Perindustrian Nomor 74 Tahun 2007 tentang Penggunaan Tanda Batikmark 'batik INDONESIA'

Peraturan Menteri Dalam Negeri Nomor 53 Tahun 2009 tentang Pakaian Dinas Pegawai Negeri Sipil

\section{Sumber Internet}

Abidin, J. (2018, Januari 3). Selayang Pandang Batik Lebak. Retrieved from Dinas Perindustrian dan Perdagangan: http:// disperindak.lebakkab.go.id/homepage/ berita/112-selayang-pandang-bati klebak.html

Admin. (2018, Oktober 3). 12 Motif Batik Lebak dan Filosofinya. Retrieved from Pemerintah Kabupaten Lebak: http://le bakkab.go.id/2018/10/03/12-motifbatik-lebak-dan-filosofinya/

Anggraini, A. P. (2019, Mei 8). Alasan Nelson Mandela Gemar Pakai Batik di Forum Dunia. Retrieved from Kompas: https:// lifestyle.kompas.com/read/2019/05/08/ 130000020/alasan-nelson-mandelagemar-pakai-batik-di-forumdunia?page $=$ all

Bapenda. (2017, Agustus 13). Potensi dan Pengembangan Wilayah di Kabupaten Lebak Banten. Retrieved from Bapenda Kabupaten Lebak: https://bapenda.leba kkab.go.id/2017/08/13/potensi-dan-pen gembangan-wilayah-di-kabupaten-leba k-banten/ 
Galih, B. (2017, Oktober 2). UNESCO Akui Batik sebagai Warisan Dunia dari Indonesia. Retrieved from Kompas: https://nasional.kompas.com/read/2017 /10/02/08144021/2-oktober-2009-unes co-kui-batik-sebagai-warisan-duniadari-indonesia

Hidayat, D. (2018, Oktober 3). Peringatan Hari Batik: Menjaga Warisan Adiluhung, Mendongkrak Ekonomi Masyarakat. Retrieved from Kabar Banten: https:// kabarbanten.pikiran-rakyat.com/lebak /pr-59613165/peringatan-hari-batik-me njaga-warisan-adiluhung-mendongkrak -ekonomi-masyarakat

Mulyana, E. (2018, April 8). Batik Lebak Jadi Magnet di Pameran Surabaya. Retrieved from Kabar Banten: https://kabarba nten.pikiran-rakyat.com/pariwisata/am p/pr-59610623/batik-lebak-jadi-magne t-di-pameran-surabaya
Shabira, P. G. (2018, Oktober 2). Mana Saja Sih Kota Penghasil Batik di Indonesia? Retrieved from Kompasiana: https://ww w.kompasiana.com/pocutghinashabira2 213/5bb2f3a7c112fe33846d5432/mana -saja-sih-kota-penghasil-batik-di-indon esia-ini-5-kota-terpopuler?page $=$ all

Soemarsono, T. (2018, Februari 13). Selamat Jalan H Moch Yas'a Mulyadi Negarawan dari Gunung Kencana. Retrieved from Kabar Banten: https://kabarbanten.pikiran-rakyat.com/ lebak/amp/pr-59609229/selamat-jalanh-moch-yasa-mulyadi-negarawan-darigunung-kencana

Staff. (n.d.). Pendidikan. Retrieved from Staff Site Universitas Negeri Yogyakarta: http://staffnew.uny.ac.id/upload/13229 9860/pendidikan/teori+motif+batik.pdf 